\title{
A Qualitative Study: Investigating the Decline in the Number of Application Cases in Maternity Campus during the COVID-19 Pandemic \\ Yavuz Bingöl ${ }^{1}$,Filiz Kuni $^{2}$,Büşra Çekirge ${ }^{3}$,Mehtap Bolat ${ }^{4}$
}

\begin{tabular}{l} 
A R T ICLE IN F O \\
\hline Article History: \\
Received 11.11 .2020 \\
Received in revised form \\
07.08 .2021 \\
Accepted \\
Available online 01.07 .2022
\end{tabular}

\begin{abstract}
Any change or threat in society makes people nervous and causes changes in their behavior. Especially if the change is health related, individuals are more careful and meticulous about protecting themselves and their families. With the Covid-19 pandemic outbreak, individuals began to behave differently; they started to work from home, do all their shopping online and avoid public areas. They started to behave particularly carefully in the case of going to hospitals where there are many other people due to the pandemic. In this study, the opinions of 30 families who had applied to the pediatric emergency service three times or more in the month before the Covid-19 outbreak were analysed after the outbreak. Evaluation of the results shows that $83 \%$ of the statements made by the families about protecting their children from diseases and the precautions which they follow when the children become sick clearly showed that staying away from enclosed and crowded environments protects their children from contracting diseases. As a result, during the Covid-19 pandemic, the social distancing policy shows us that the restriction on leaving the house for children under 18 is effective.
\end{abstract}

(CTUARA Journal. All rights reserved

\section{Keywords:}

Pediatric emergency, admission to hospital, COVID-19

\section{INTRODUCTION}

Emergency services are an important area of health care where patient density is most commonly permanently high. That is why the triage process should be arranged appropriately in order for medical staff to assess and stabilize each patient and to start the treatment without wasting any time (Başol, Çelik, Ayan, Esen, Koç and Savaş, 2014). The main purpose of an emergency department is to prevent the deterioration of any injury or disability and to prevent probable death in the event of an unexpected illness or injury (Aslan, Akman Dömbekçi \& Yağcı Özen, 2017). It is not possible to prevent or limit patients from applying to or arriving at an emergency department. Accordingly, the burden of emergency services is increasing on a daily basis (Altıntop \& Tatlı, 2017). The effect of the easy accessibility of medical care as a reason for this situation is undeniable (Diserens, Egli, Fustinoni, Santos-Eggimann, Staeger \& Hugli, 2015).

In the background studies reviewed, the desire of patients to benefit from health services as quickly as possible, the belief that tertiary health institutions are more satisfactory and active than primary health-care institutions, and the provision of more comprehensive laboratory facilities have been considered to be the most significant reasons for the inappropriate use of pediatric emergency services (Karakas, Özdemir, Kılıç \& Akbulut, 2020). According to a report published by Turkey's Ministry of Health (MoH) in 2017, there were 296 million patients who had applied to a pediatric emergency department in the first nine months of that year and $25.9 \%$ of these were genuine emergency applications; child emergency applications were reported to be in the 14th place and constituted $2.61 \%$ of all applications (an average of 7.7 million applications) (Karakas, Özdemir, Kılıç \& Akbulut, 2020, p.67-74).

This volume of attendances throws the health-care services into disorder and causes prolonged waiting times in emergency departments, delays in the treatment of important diseases, a decrease in the quality of care due to decreased patient satisfaction, a decrease in personnel efficiency and security problems (Bozan, Oktay \& Göksu, 2005, p.5-13).

The high rate of referrals to emergency services and people's preference for them over primary health-care facilities draw attention. During the Covid-19 pandemic, it was observed that the number of patients admitted to the pediatric emergency department of our hospital decreased rapidly compared with the previous year. The aim of this study is therefore to determine the factors which had direct and/or indirect effects on the decrease in the number of patients admitted to pediatric emergency department.

\section{METHODOLOGY}

This study is the product of qualitative research which collected data using the semi-structured interview technique. Participant children were selected by random sampling from families who had made three or more applications to the emergency services between 15 March and 15 May 2019, which preceded the

'Sakarya Training and Research Hospital,yb2580@gmail.com, orcid.org/0000-0001-6723-7051 ${ }^{2}$ Sakarya Training and Research Hospital,filizkuni@ hotmail.com, orcid.org/0000-0001-8796-7617

${ }^{3}$ Sakarya Training and Research Hospital,bcekirge@ @mail.com, orcid.org/0000-0002-0298-7748

${ }^{4}$ Sakarya Training and Research Hospital,mehtapbolat54@gmail.com, orcid.org/0000-0002-5876-8536 
start of the Covid-19 pandemic. With this sampling method, all of the elements involved had an equal chance of being selected (Karasar, 2006, p.113).

In order to protect the health of the children's parents, taking into account the social distancing policy, families were contacted by telephone instead of face-to-face interviews and their answers about their ideas about what to do when their children become sick during the pandemic and how to apply to the hospital were registered in a written form.

Although it is known that face-to-face interviewing is considered to produce more optimistic responses than telephone interviews in qualitative studies and that telephone interviews are approached with prejudice and are less preferred because of the reduction in the quality of the research, there is no evidence to prove these claims (Novick, 2008, p.391-398). On the contrary, different qualitative studies have shown the benefits provided by telephone conversations, such as reaching more people in a shorter time, correcting problems immediately and reducing effort and cost (Çelik \& Arıkan, 2012, p.77-87).

Throughout the study and in the reporting, the parents of the participants were assured that their identity and that of their children would be kept anonymous. Frequency and percentage tables were created using SPSS software which was also used for the analysis of the responses.

\section{FINDINGS}

The first question put to the parents of the patients was whether their children had shown any symptoms of disease during the pandemic. The purpose of this question was to determine whether the low number of applications to the emergency department was due to a decrease in diseases or because they had applied to different health institutions instead. The responses to this question are shown in Table 1.

Table 1: Childhood illness in the Covid-19 period: frequency and percentages

\begin{tabular}{lll}
\hline Symptoms & f & $\%$ \\
\hline Did not get sick & 24 & 80 \\
Sore throat & 3 & 10 \\
Runny nose and cough & 2 & 6.7 \\
Fever & 1 & 3.3 \\
\hline
\end{tabular}

As Table 1 shows, 24 of the 30 participants ( $80 \%$ ) answered that their children did not get sick; three $(10 \%)$ had had a sore throat, two $(6.7 \%)$ had had a runny nose and cough, and one $(3.3 \%)$ had shown fever symptoms.

The second question to the participants who had answered that their child was sick asked what they did during the child's illness. This question was designed to investigate the attitude of families who had encountered a child's disease during the pandemic on the basis their frequent previous emergency applications. Their responses are presented in Table 2.

Table 2: Treatment status of children who became sick during the Covid-19 pandemic: frequency and percentages

\begin{tabular}{lcc}
\hline Treatment & $f$ & $\%$ \\
\hline Attended a primary health-care center & 1 & 16.6 \\
Used medication already available at home & 2 & 33.3 \\
Consulted a specialist doctor & 2 & 33.3 \\
Drank herbal tea & 1 & 16.6 \\
\hline
\end{tabular}

Table 2 shows the treatment status of children who were sick during the Covid-19 pandemic. Two (33.3\%) of the parents of the sick children said that they used medication already available at home and two (33.3\%) had consulted a specialist doctor. One had attended a primary health-care facility and one had given the child herbal tea to drink. 
The third question put to the participating parents asked whether they had undertaken any extra measures to protect their child's health during the pandemic. This question explored the reasons for the decrease in the number of applications made to our hospital. The responses given by the parents to this question are presented in Table 3.

Table 3: Practices carried out during the Covid-19 pandemic to protect the health of their children: frequency and percentages

\begin{tabular}{lll}
\hline Additional precautions & $\mathrm{f}$ & $\%$ \\
& & \\
\hline We did not do anything additional & 13 & 43.3 \\
Enhanced nutrition with organic foods & 9 & 30 \\
Frequent hand washing; increased approach to personal hygiene (two & 4 & 13.3 \\
people who responded to other answers were also included in this & & \\
response) & 6 & 20 \\
Used probiotics and/or vitamin supplements & 6 \\
\hline
\end{tabular}

Table 3 shows the responses given by parents about additional measures taken to protect the health of their children during the pandemic. Most of them, thirteen people (43.3\%) said that they did not do anything additional. Nine people (30\%) who had done something extra to protect their children's health stated that they had given greater importance to natural food, six $(20 \%)$ had given their child probiotics and vitamins, and four $(13.3 \%)$ had increased personal hygiene, such as frequent hand washing.

We noted that the number of pediatric patients admitted to our hospital decreased during the pandemic by $81 \%$ compared with the same time period in previous years. We asked the parents for their opinion about the reason for this decrease. We therefore asked a fourth question to investigate the common factors influencing parental attitude in causing the decrease in hospital admissions. The responses are presented in Table 4.

Table 4: Reasons for the decrease in applications to pediatric emergency services during the Covid-19 pandemic: frequency and percentages

\begin{tabular}{lcc}
\hline Reasons given & $f$ & $\%$ \\
& & \\
\hline I have no idea & 3 & 10 \\
Encouraging organised and healthy eating at home & 2 & 6.6 \\
Not being in a crowded environment (park, school, street, shopping mall, & 25 & 83.3 \\
market, family visit) & &
\end{tabular}

The majority of the parents, $25(83 \%)$ responded that they deliberately avoided crowded places. Three $(10 \%)$ stated that they had no idea why hospital attendances had reduced and two $(6.6 \%)$ said that they ate healthy and nutritious meals at home.

\section{CONCLUSIONS}

Covid-19, which has recently been widespread across the world and not just in Turkey, has caused a number of changes in society and in individual behavior (Almathkoori, Bouchareb \& Flores-Tena , 2020 ;Dannan, 2020; Karagoz, 2020; Makhzoum \& Jabbour,2020). This study was carried out in order to identify the reasons for the fall in the number of attendances at child emergency services during the pandemic.

During the pandemic, individuals' awareness of health has increased and they have begun to be more careful and more cautious about their lifestyle and consequently caring more about their health. 
As a result of this increase in caution, there has been a decrease in reported diseases such as flu and colds, apart from the Covid-19 epidemic. Within the scope of this review, the first question put to the participants was about the state of the sickness of their children during Covid-19. Their responses showed that more people than usual stated that their children did not get sick. During the pandemic, the rate of sickness in children may have decreased as a result of the measures taken by parents regarding family health, such as having healthy nutrition and reducing their contact with crowded places outside the home.

There were also changes regarding instances of sick individuals going to the hospital, and parents had become particularly more cautious about taking their children to the hospital. The number of parents who took their children to the hospital has decreased enormously, most importantly because they wanted to prevent the transmission of the Covid virus. Participants stated that they had first tried to treat their sick children with home remedies and had then taken them to a specialist doctor.

During the pandemic, families tended to choose different methods to protect their health, especially parents who tried different methods and used supplements to strengthen their immune system. In order to know whether these measures were also taken for their children, the parents were asked about any measures which they had taken to protect the health of their children during the pandemic. Their responses showed that most of them did not do anything additional. The poor likelihood of contagion of the Covid virus for children may have led parents to believe that they did not need to do anything extra. Nine parents, however, stated that they had opted to provide more natural foods for their children. In fact, the responses to both questions showed that the parents did not have enough information about what to do to prevent them from contracting or spreading the Covid-19 virus.

When there is an emergency, people will avoid going to crowded public areas. The results of the study support this statement. When the parents were asked about the reasons for the decrease in applications to the pediatric emergency services during the pandemic, most of their responses were that the social distancing was effective. This result shows that during the pandemic, individuals deliberately avoided crowded environments, including the hospital, unless it was an emergency.

The responses given to one question make it possible to say that the social distancing measures introduced in Turkey played an active role in protecting the health of children. At the same time, when we look at the responses to the second and third questions, we can say that the isolation of children from wider society and maintaining a healthy diet are effective in protecting children's health. On the other hand, children with symptoms such as a cough, a runny nose or a fever, which are common reasons for child admission to the emergency department, did not head to the hospital but received their treatments at home. Also, the fact that children with a sore throat are referred by the family doctor or a specialist doctor to the emergency department under an appointment system and the consequent absence of unnecessary applications to emergency services during the pandemic led to the decrease in number of applications to our emergency services.

The findings of this study enable a series of recommendations to be made in regard to preventing children from contracting disease: Common areas used by children should be disinfected frequently and under suitable conditions. Parents should pay more attention to their children's eating habits and healthy and nutritious meals should be provided. Unless it is absolutely necessary, children should be kept away from densely crowded and badly ventilated areas such as shopping malls and indoor playgrounds. Hand washing and hygienic habits should be instilled in children. Children who are sick should not be taken to areas such as schools, kindergartens and parks before they have returned to full health. In order to reduce overcrowding in emergency services, priority should be given to an appointment-controlled visit to primary health-care services or to a physician. The measures introduced by the government to protect the public in extraordinary situations must be strictly observed throughout the country by eliminating potentially negative situations which may be experienced.

\section{REFERENCES}

Almathkoori,H., Bouchareb,R. \& Flores-Tena,M.J. (2020). Physical activity practitioners: Reducing infection with coronavirus. International Journal of Educational Research Review,5(4),335-342.

Altıntop, İ. \& Tatlı, M. (2017). Acil servis yoğunluğuna farklı bir bakış: Anket çalışması. Journal of Anatolian Medical Research, 2(1): 45-57. 
Aslan, Ş., Akman Dömbekçi H. \& Yağcı Özen M. (2017). Acil sağlık hizmetlerine gereksiz başvuruların azaltılmasında önemli bir etken: Sağlık okuryazarlığı. Avrasya Sosyal ve Ekonomi Araştırmaları Dergisi (ASEAD), 4(12): 47-62.

Başol, N., Çelik, Y/, Ayan, M., Esen, M., Koç, İ. \& Savaş, A.Y. (2014). Acil servis yoğunluğunun bir sebebi olan enjeksiyon amaçlı başvuruların değerlendirilmesi. Gaziosmanpaşa Üniversitesi Tıp Fakültesi Dergisi, 6(4): 258-268

Bozan, H., Oktay, C. \& Göksu, E. (2005). Türkiye'de Acil Servise Başvuran Hastaların Demografik Özellikleri. Türkiye Acil Tıp Dergisi, 5(1): 5-13.

Çelik, S. \& Arıkan, A. (2012). Öğretmen Yetiştirme Programlarının İngilizce Öğretmen Adaylarını İlköğretimde İngilizce Öğretimine Ne Kadar Hazırladığına Yönelik Nitel Bir Araştırma Pamukkale. Üniversitesi Ĕ̆itim Fakültesi Dergisi Sayı, 32 (Temmuz 2012/II), ss. 77-87.

Dannan,A. (2020). The effect of a simple reward model on the academic achievement of Syrian dental students. International Journal of Educational Research Review,5(4),308-314.

Diserens, L., Egli, L., Fustinoni, S., Santos-Eggimann, B., Staeger P. \& Hugli O. (2015). Emergency department visits for non-life-threatening conditions: Evolution over 13 years in a Swiss urban teaching hospital, Swiss Medical Weekly, 145: 14123.

Karagöz,S. (2021). Evaluation of distance education: The sample of guidance and counseling students. The Universal Academic Research Journal,3(1),18-25

Karakas, N.M., Ozdemir, B., Kilic, S. \& Akbulut, O. (2020). Ebeveynleri Çocuk Acile Getiren Nedenler: 4 Yıllık İzlem. Osmangazi Journal of Medicine, 42(1): 67-74.

Karasar, N. (2006). Bilimsel Araştırma Yöntemi. Ankara: Nobel Yayıncllık syf:113.

Makhzoum,V. \& Jabbour,M. (2020). Critical thinking and it is role in facing Coronavirus. International Journal of Educational Research Review,5(4),389-406.

Novick, G. (2008). Is there a bias against telephone interviews in qualitative research? Research in Nursing and Health, 31(4): 391-398. 